\title{
Hormonal basis of variation in oestrous cyclicity in selected strains of mice*
}

\author{
D. D. DeLeon $\dagger$, M. B. Zelinski-Wooten $\ddagger$ and M. S. Barkley \\ Department of Animal Physiology, University of California, Davis, CA 95616, USA
}

\begin{abstract}
Summary. Reproductive hormone secretion and ovarian LH receptor content were studied during the oestrous cycle of mice that differed in fertility after genetic selection. Strain variation in the secretory pattern of progesterone was observed along with differences in the timing and magnitude of prolactin release. Scatchard analysis showed similar affinities of the $\mathrm{LH}$ receptor for $\mathrm{hCG}$ in strains with increased or decreased reproductive performance, with a single order of binding sites during both pro-oestrus and dioestrus. The number of unoccupied $\mathrm{LH}$ receptors during pro-oestrus was greatest in mice with increased reproductive performance. These results provide evidence that trait selection can change gonadotrophin receptor concentration and the dynamics of hormone secretion during the oestrous cycle of the mouse.
\end{abstract}

Keywords: genotype; oestrous cycle; prolactin; progesterone; LH receptor; mouse

\section{Introduction}

Oestrous cyclicity in the mouse is regulated by a wide variety of factors. Some of these are derived from the social environment in the form of chemosignals produced by both sexes or as visual and tactile stimuli, all of which influence the composition and frequency of the cycle (Drickamer, 1975; Aron, 1979; DeLeon \& Barkley, 1987). Oestrous cycle regularity is also affected by prior intrauterine position and age (Vom Saal et al., 1981; Nelson et al., 1982). A role for genetic factors was demonstrated by the study of mice selected for reproductive performance and other traits (Nobunaga, 1973; Barkley \& Bradford, 1981). Increased regularity of the cycle was associated with improved prenatal survival and large litters, while decreased fertility was associated with prolongation of the cycle and anoestrus. In addition, a lengthened pro-oestrous/oestrous phase was positively correlated with changes in ovulation rate, suggesting substantial heritabilities for the physiological determinants of these traits (Barkley \& Bradford, 1981).

Changes in endocrine function have also occurred as a correlated response to selection for reproductive performance as determined by the study of pregnant mice (Barkley et al., 1978, 1979). However, investigation of endocrine function during the oestrous cycle of strains derived from the same base population has been limited to gonadotrophin release (Murr et al., 1973; Spearow, 1980; Bradford et al., 1980) and oestrogen secretion (Barkley et al., 1985). The present study was undertaken to define further the effects of genetic selection on endocrine function during the oestrous cycle by examining the secretory patterns of prolactin and progesterone in 5 selected strains of mice. Ovarian $\mathrm{LH}$ receptor content was also studied in a strain with increased fertility and one with decreased reproductive performance. 


\title{
Materials and Methods
}

\begin{abstract}
Animals. The mice used in this study were from 5 strains derived from the same base population produced by crossing 4 inbred lines (C57BL/6, AKR, C3H and DBA/2). The strains examined include an unselected control line (C) and 4 lines selected for various traits: S1, large litters; $\mathbf{E}$, high embryo survival; $\mathrm{CN}$-, small litters; and G, rapid post-weaning weight gain (Bradford, 1968, 1969, 1971). Random mating was used in the control line and, to minimize inbreeding and genetic drift, each generation of Line $C$ was maintained by mating 18 males to 36 females through to generation 33, after which 18 breeding pairs were maintained for each subsequent generation. This mating procedure or slight variations thereof was also used to produce the selected lines. Inbreeding beyond that existing in the base population ( $25 \%$ as a result of crossing 4 highiy inbred lines) accumulated at a very slow rate, e.g. $<1 \%$ per generation in the control line in which performance was extremely stable in terms of growth and litter size for 80 generations. The rate of inbreeding in the selected lines was slightly higher, e.g. $<2 \%$ in Line $G$, but again these lines maintained a high performance for the selective traits. A description of the 5 strains is provided in Table 1 .
\end{abstract}

Table 1. Ovulation rate, prenatal survival, litter size, and oestrous cyclicity of mice in 4 selected lines and an unselected control line developed from a common base population (composite data from Barkley \& Bradford, 1981)

\begin{tabular}{|c|c|c|c|c|c|}
\hline Line & $\begin{array}{l}\text { Selection } \\
\text { criterion }\end{array}$ & $\begin{array}{l}\text { Oestrous } \\
\text { cyclicity* }\end{array}$ & $\begin{array}{l}\text { Ova or } \mathrm{CL}^{\dagger} \\
\text { (a) }\end{array}$ & $\begin{array}{l}\text { Normal fetuses } \\
\text { at } 16 \text { days or } \\
\text { no. born } \\
\text { (b) }\end{array}$ & $\begin{array}{c}\text { Prenatal } \\
\text { survival } \\
\text { (a/b) }\end{array}$ \\
\hline $\mathrm{C}$ & Unselected & Control & $10 \cdot 1 \pm 0 \cdot 29$ & $7 \cdot 8 \pm 0.21$ & $0 \cdot 77$ \\
\hline $\mathrm{CN}-$ & Small litters & Irregular & $10 \cdot 1 \pm 0 \cdot 30$ & $5.8 \pm 0.27$ & $0 \cdot 57$ \\
\hline $\mathrm{S} 1$ & Large litters & Regular & $17.4 \pm 0.43$ & $15.3 \pm 0.31$ & 0.88 \\
\hline $\mathrm{E}$ & High embryo survival & Regular & $11 \cdot 6 \pm 0.20$ & $10 \cdot 2 \pm 0 \cdot 21$ & $0 \cdot 88$ \\
\hline G & Rapid 2l-42-day gain & Irregular & $16 \cdot 0 \pm 0 \cdot 55$ & $8 \cdot 1 \pm 0.34$ & 0.51 \\
\hline
\end{tabular}

*During a 25 -day period in females aged 8-12 weeks; $27-36$ animals per line.

+ In females mated at 8-10 weeks of age: $24-58$ animals per line; mean \pm s.e.m.

¥Based on approximately 100 females per line also mated at 8-10 weeks of age; mean \pm s.e.m.

As a correlated response to selection, mice in Lines $\mathrm{CN}$ - and $\mathrm{G}$ have irregular cycles and frequent periods of anoestrus or pseudopregnancy, in contrast to those of Lines SI and E which have regular cycles (Barkley \& Bradford, 1981). Improved reproductive performance in mice of Lines SI and E is further characterized by an increase in ovulation rate compared to Lines $\mathrm{C}$ and $\mathrm{CN}$-. Although ovulation rate has also increased in Line $\mathrm{G}$, prenatal survival has decreased in this line as well as in Line CN- (Table 1). Breeding stocks of all lines were housed in the same animal room maintained at $22-24^{\circ} \mathrm{C}$ and illuminated $14 \mathrm{~h} /$ day (lights on $05: 00-19: 00 \mathrm{~h}$ ). Purina rodent chow ( $\$ 5001$, Agronomics, Woodland, CA, USA) and water were supplied ad libitum.

Animals were weaned at 21-25 days of age according to size and were caged by sex (4-6/cage). At 6 weeks of age females were permanently identified by notching one ear and were subsequently housed in cages divided by a wire mesh. Three females were placed on one side of a divided cage and 1 male was housed on the other side to expose the females to a high level of male pheromonal stimulation.

Oestrous cyclicity. Females and males were placed in separate compartments in divided cages. After a 2-week acclimatization period, vaginal smears were taken daily by saline lavage between 09:00 and 11:00 h. The vaginal fluid obtained was examined in stained (new methylene blue), wet preparations. The criteria used for identification of cycle stages have been described previously (DeLeon \& Barkley, 1987).

Blood and tissue collection. Mice were killed by decapitation and trunk blood was collected over heparinized funnels at 16:00, 18:00, 20:00 and 22:00 h during pro-oestrus and at 24:00,04:00, 16:00 and 20:00 $\mathrm{h}$ during oestrus, metoestrus and dioestrus from females that had shown at least 2 normal oestrous cycles. Vaginal smears were examined immediately after decapitation to determine stage of cycle at the time of killing. Only samples from animals that met the criteria outlined in Table 2 were included in the study. Samples were collected in a manner designed to avoid stress-induced prolactin secretion (Barkley et al., 1978). The blood obtained after decapitation was centrifuged and the plasma was stored at $-20^{\circ} \mathrm{C}$ until radioimmunoassay (RIA) for prolactin and progesterone. Ovaries for $\mathrm{LH}$ receptor studies were collected from females of Lines $S 1$ and $G$ killed between 12:00 and 15:00 h during each cycle stage. These strains were chosen for study because they have responded to selection with an increased ovulation rate, with more ova available for fertilization, but females in Line $\mathrm{S} 1$ have a larger number of young born because embryo loss is nearly $50 \%$ in Line $\mathrm{G}$ (Table 1). Furthermore, Line-S1 females are characterized by regular oestrous cycles while oestrous cyclicity is irregular in Line G females (Barkley \& Bradford, 1981). The ovaries were dissected from adhering fat pad, immediately frozen in a solid $\mathrm{CO}_{2}$ /acetoneibathland stored at ie 70 . $\mathrm{C}_{\text {ca }}$. com at 04/26/2023 $07: 32: 34 \mathrm{AM}$ 
Table 2. Criteria for blood sample collection during the oestrous cycle, to ensure collection of samples during a short oestrous cycle

\begin{tabular}{|c|c|c|c|c|c|}
\hline \multicolumn{2}{|l|}{ Stage of cycle } & \multicolumn{4}{|c|}{ Time of killing (h) } \\
\hline Pro-oestrus (PE) & $\begin{array}{l}\text { Vaginal smear in morning } \\
\text { Vaginal smear at killing }\end{array}$ & $\begin{array}{c}16: 00 \\
\text { PE } \\
\text { PE }\end{array}$ & $\begin{array}{c}18: 00 \\
\text { PE } \\
\text { PE }\end{array}$ & $\begin{array}{c}20: 00 \\
\text { PE } \\
\text { PE }\end{array}$ & $\begin{array}{c}22: 00 \\
\text { PE } \\
\text { PE }\end{array}$ \\
\hline Oestrus (E) & $\begin{array}{l}\text { Vaginal smear in morning } \\
\text { Vaginal smear at killing }\end{array}$ & $\begin{array}{c}24: 00 \\
\text { PE } \\
\text { E }\end{array}$ & $\begin{array}{c}04: 00 \\
\text { PE } \\
\text { E }\end{array}$ & $\begin{array}{c}16: 00 \\
\text { E } \\
\text { E }\end{array}$ & $\begin{array}{c}20: 00 \\
E \\
E\end{array}$ \\
\hline Metoestrus (ME) & $\begin{array}{l}\text { Vaginal smear in morning } \\
\text { Vaginal smear at killing }\end{array}$ & $\begin{array}{c}24: 00 \\
\text { E } \\
\mathrm{ME}\end{array}$ & $\begin{array}{c}04: 00 \\
\mathrm{E} \\
\mathrm{ME}\end{array}$ & $\begin{array}{l}16: 00 \\
M E \\
M E\end{array}$ & $\begin{array}{c}20: 00 \\
\text { ME } \\
\text { ME }\end{array}$ \\
\hline Dioestrus (DE) & $\begin{array}{l}\text { Vaginal smear in morning } \\
\text { Vaginal smear at killing }\end{array}$ & $\begin{array}{c}24: 00 \\
\mathrm{ME} \\
\mathrm{DE}\end{array}$ & $\begin{array}{c}04: 00 \\
\mathrm{ME} \\
\mathrm{DE}\end{array}$ & $\begin{array}{l}16: 00 \\
D E \\
D E\end{array}$ & $\begin{array}{c}20: 00 \\
D E \\
D E\end{array}$ \\
\hline
\end{tabular}

Radioimmunoassays. Plasma concentrations of prolactin were measured using an homologous RIA described by Barkley et al. (1982). Highly purified mouse prolactin with a potency of $25 \mathrm{i} . \mathrm{u} . / \mathrm{mg}$, kindly provided by $\mathrm{Dr}$ Y. N. Sinha (Whittier Institute for Diabetes and Endocrinology, La Jolla, CA, USA), was used as standard and for iodination by the chloramine-T procedure. Rabbit anti-mouse prolactin serum was obtained from Dr A. F. Parlow (Pituitary Hormones and Antisera Center, Harbor UCLA Medical Center, Torrance, CA, USA). This antiserum has $<0.5 \%$ cross-reaction with mouse growth hormone (Barkley et al., 1982). The sensitivity of the assay was 0.02 ng mouse prolactin/assay tube. The inter-assay coefficient of variation was $12.8 \%$, with an intra-assay coefficient of variation of $8 \cdot 3 \%$.

The RIA procedure used to measure progesterone was as described by Barkley et al. (1979). The antiserum (GDN \#337) used in the assay was produced in sheep immunized against progesterone- $11 \beta$-succinyl-bovine serum albumin and was provided by Dr G. D. Niswender (Department of Physiology and Biophysics, Colorado State University, Fort Collins, CO, USA). A detailed description of the specificity of this antiserum has been reported (Gibori et al., 1977). Briefly, cross-reaction with $17 \alpha$-hydroxyprogesterone is $2.9 \%$; $5 \alpha$-pregnane- 3,20 -dione is $4.4 \%$, with the crossreaction of other progestagens including pregnenolone ranging from 0.2 to $1 \cdot 7 \%$. Recovery of $\left[{ }^{3} \mathrm{H}\right]$ progesterone from serum samples extracted once with petroleum ether was $90.5 \%$. The inter-assay coefficient of variation was $16.6 \%$, with an intra-assay coefficient of variation of $13.0 \%$, in close agreement with the assay performance as previously reported (inter-assay and intra-assay coefficients of variation were $16 \cdot 3 \pm 3 \cdot 1 \%$ and $10 \cdot 9 \pm 1 \cdot 2 \%$, respectively; Gibori et al., 1977).

LH receptor binding analysis. Highly purified hCG (CR117), generously provided by NIDDK, was labelled with $1 \mathrm{mCi}{ }^{125} \mathrm{I}$ (Amersham, Arlington Heights, IL, USA). Using a lactoperoxidase procedure (Morrison \& Bayse, 1970), $1.5 \mu \mathrm{g}$ lactoperoxidase (Sigma, St Louis, MO, USA) and $100 \mathrm{ng} \mathrm{H}_{2} \mathrm{O}_{2}$ were added to $10 \mu \mathrm{g} \mathrm{hCG}$ and incubated for $8 \mathrm{~min}$ at $4^{\circ} \mathrm{C}$. The specific activity of each preparation of radioiodinated hormone was determined by a selfdisplacement radioreceptor assay (Ketelslegers et al., 1975) utilizing pooled ovarian homogenates (0.1 ml/tube) collected from mice during pro-oestrus ( 12 ovaries/pool). In the present experiment, 6 preparations of radioiodinated hCG were used that varied from 27 to $57 \mu \mathrm{Ci} / \mu \mathrm{g}$ protein (calculated using a molecular weight of 46000 for hCG, $66 \%$ counting efficiency and corrected for maximum specific binding). Maximum specific binding ranged from 51 to $62 \%$ when incubated with $150-200 \mu \mathrm{g}$ protein/tube. Specific binding of radioiodinated hCG was linear up to $100 \mu \mathrm{g}$ ovarian protein; therefore, samples of 35-50 $\mu \mathrm{g} /$ tube were used in the assays. Ovarian protein was determined by the method of Bradford (1976), using the Pierce Coomassie protein assay kit (Pierce Chemical Co., Rockford, IL, USA).

The procedure used to measure unoccupied LH receptors was similar to that reported by Catt $e$ al. (1972), except that $0.02 \mathrm{M}$-sodium phosphate $0.14 \mathrm{M}-\mathrm{NaCl}-0.1 \%$ gelatin $(\mathrm{pH} \mathrm{7.2)}$ buffer was used. Saturation analyses were performed by incubating ovarian homogenates for $18 \mathrm{~h}$ at $22^{\circ} \mathrm{C}$ with increasing concentrations of radioiodinated hCG (25-300 $\times 10^{3}$ c.p.m./tube) in the absence (total binding) or presence (non-specific binding) of a 1000-fold excess of unlabelled hCG (Pregnyl; Organon, Inc., El Monte, CA, USA). Polyethylene glycol $(20 \% \mathrm{w} / \mathrm{v}$; Carbowax 8000 , Fisher, NJ, USA) was utilized to separate bound hormone from free hormone (Bramley \& Ryan, 1978). Specific binding represents the difference between total binding and non-specific binding. From the saturation analyses, the equilibrium dissociation constant $\left(K_{\mathrm{d}}\right)$ and receptor concentration $\left(\mathrm{R}_{\mathrm{t}}\right)$ were determined according to the procedure of Scatchard (1949); $K_{\mathrm{d}}=-(1 / \mathrm{slope}), \mathrm{R}_{\mathrm{t}}=x$ intercept. Results were expressed as $\mathrm{pmol} / \mu \mathrm{g}$ protein.

Statistical analysis. Data were tested for homogeneity of variances and it was determined that no transformations were necessary before analyses of variance and Duncan's new multiple range tests. Only differences between means at $P \leqslant 0.05$ were considered significant. 


\section{Results}

The secretory pattern of prolactin is shown in Fig. 1. Strain differences in prolactin secretion were minimal during oestrus, metoestrus and dioestrus. A dramatic variation in prolactin secretion occurred during late pro-oestrus-early oestrus $(22: 00-24: 00 \mathrm{~h})$ when mice of Lines $\mathrm{CN}$ - and $\mathrm{G}$ (both characterized by poor reproductive performance) showed increased (2-4-fold) prolactin concentrations compared to the other 3 lines $(\mathrm{C}, \mathrm{S} 1$ and $\mathrm{E})(P \leqslant 0.05)$. A comparison of maximal values of prolactin and the time at which these were present in the circulation is provided in Table 3. In Lines $\mathrm{C}, \mathrm{Sl}$ and $\mathrm{G}$, prolactin concentrations were highest during pro-oestrus, whilst in Lines $\mathrm{CN}$ - and $\mathrm{E}$, prolactin values were maximal during early oestrus.

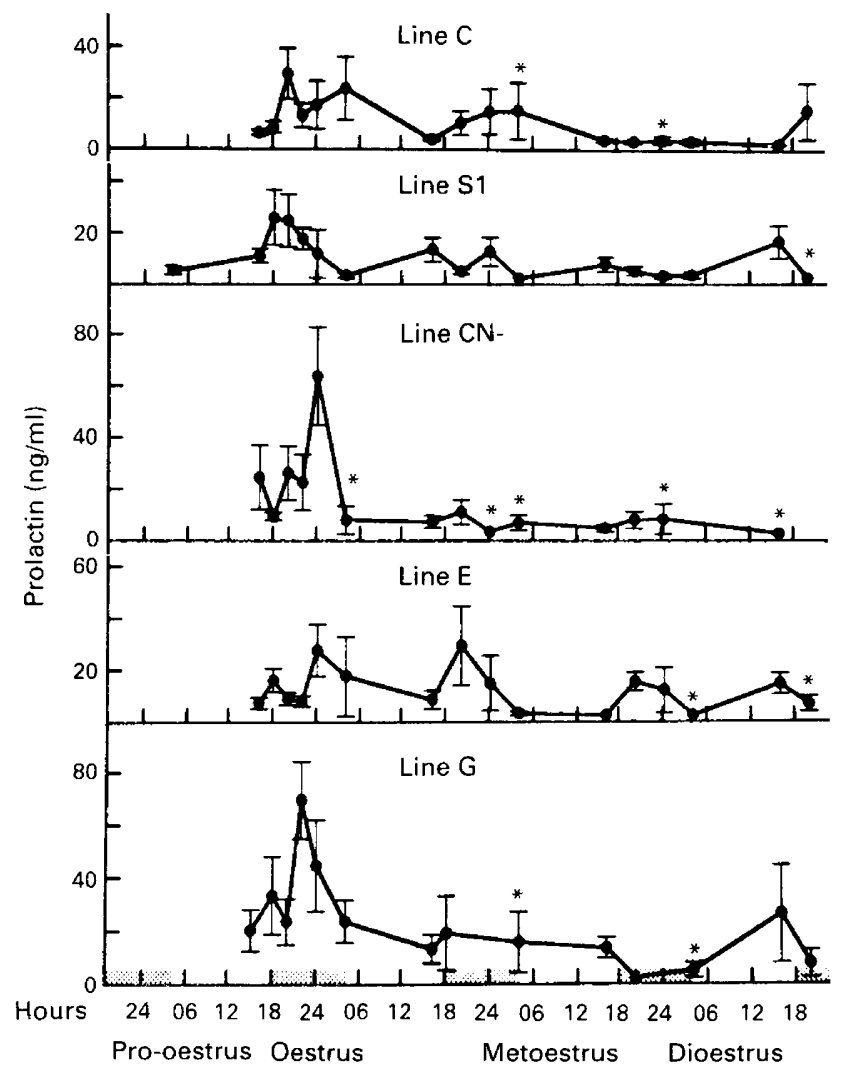

Fig. 1. Prolactin concentrations in plasma during the oestrous cycle in mice of Lines $\mathrm{C}, \mathrm{S} 1$, $\mathrm{CN}-, \mathrm{E}$ and $\mathrm{G}$. Each point on the graph represents the mean \pm s.e.m. for 5-11 animals, with the exception of 3-4 mice/group where indicated $(*)$.

The pattern of progesterone secretion during the oestrous cycle in the control and selected lines is illustrated in Fig. 2. Variation in the pattern was evident, although the maximal values of progesterone did not differ significantly among the selected strains. A secondary rise in progesterone production was apparent during metoestrus in mice selected for increased embryo survival (Line E), but progesterone concentration did not differ during this stage of the cycle from that measured at the time of maximal secretion (24:00 h oestrus). A relatively stable progesterone output during pro-oestrus distinguished Line S1 mice from those in the other selected lines. In Line CN- (small

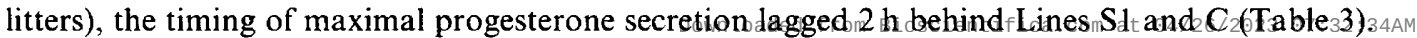


Table 3. Maximal prolactin and progesterone values among selected strains of mice

\begin{tabular}{|c|c|c|c|c|c|}
\hline \multirow[b]{2}{*}{ Strain } & & \multicolumn{2}{|c|}{ Prolactin } & \multicolumn{2}{|c|}{ Progesterone } \\
\hline & & Peak values & Pro-oestrus & Peak values & Pro-oestrus \\
\hline $\mathrm{C}$ & (unselected control) & $29 \cdot 3 \pm 9 \cdot 9$ & $20: 00 \mathrm{~h}$ & $42 \cdot 9 \pm 8.5$ & $18: 00 \mathrm{~h}$ \\
\hline SI & $\begin{array}{l}\text { (large litter size; } \\
\text { regular cycles) }\end{array}$ & $25.9 \pm 10.7$ & I8:00 h & $29.0 \pm \quad 5.8$ & $18: 00 \mathrm{~h}$ \\
\hline $\mathrm{CN}-$ & $\begin{array}{l}\text { (small litter size; } \\
\text { irregular cycles) }\end{array}$ & $63 \cdot 6 \pm 18 \cdot 9$ & $\begin{array}{l}24: 00 \mathrm{~h} \\
\text { (oestrus) }\end{array}$ & $53 \cdot 6 \pm 8 \cdot 1$ & $20: 00 \mathrm{~h}$ \\
\hline $\mathrm{E}$ & $\begin{array}{l}\text { (high embryo survival; } \\
\text { regular cycles) }\end{array}$ & $27 \cdot 5 \pm 9 \cdot 9$ & $\begin{array}{l}24: 00 \mathrm{~h} \\
\text { (oestrus) }\end{array}$ & $59 \cdot 5 \pm 14 \cdot 9$ & $\begin{array}{l}24: 00 \mathrm{~h} \\
\text { (oestrus) }\end{array}$ \\
\hline G & $\begin{array}{l}\text { (rapid weight gain; } \\
\text { irregular cycles) }\end{array}$ & $69 \cdot 5 \pm 14 \cdot 8$ & $22: 00 \mathrm{~h}$ & $40 \cdot 8 \pm 10 \cdot 0$ & $\begin{array}{l}24: 00 \mathrm{~h} \\
\text { (oestrus) }\end{array}$ \\
\hline
\end{tabular}

*Mean \pm s.e.m.

Peak values of progesterone were attained during pro-oestrus in mice of Lines $\mathrm{C}$ and $\mathrm{CN}$-. Progesterone secretion also increased during pro-oestrus in Line $\mathrm{G}$ and remained elevated at 24:00 h of oestrus. In Line $\mathrm{E}$ mice, the highest peripheral value of progesterone was found at 24:00 h of oestrus.

Characteristics of the specific binding of iodinated hCG to ovarian homogenates indicated that a concentration of $13-21 \mathrm{fmol} /$ tube $\left(300 \times 10^{3}\right.$ c.p.m.) saturated the $\mathrm{LH}$ receptor in $30-50 \mu \mathrm{g}$ protein in mice of Lines $S 1$ and $G$ and at all cycle stages studied. Non-specific binding of $h C G$ at the saturating concentration represented $18 \pm 2.0$ and $17 \pm 1.5 \%$ of the total binding during prooestrus for Lines S1 and G, respectively. During dioestrus, non-specific binding of hCG to ovarian homogenates from $\mathrm{S} 1$ and $\mathrm{G}$ mice represented $18 \pm 0.6$ and $12 \pm 1.5 \%$, respectively. Saturation analyses performed on ovaries collected from each strain at oestrus and metoestrus indicated little specific binding (34\%), i.e. a preponderance of non-specific binding $(66 \%)$. It was therefore not possible to quantify available LH receptors during these stages of the oestrous cycle.

Scatchard (1949) analyses of the saturation data for the specific binding of iodinated hCG to ovarian homogenates during pro-oestrus and dioestrus are presented in Fig. 3. No curvature of the Scatchard plots was revealed following linear regression, i.e. these data show linear Scatchard plots $\left(r^{2}=0.93\right.$ and 0.94 for $\mathrm{S} 1$ and $\mathrm{G}$ mice respectively, during pro-oestrus; 0.97 and 0.96 for $\mathrm{S} 1$ and $\mathrm{G}$ mice, respectively, during dioestrus) indicative of a single order of unoccupied LH receptors. In the 2 strains examined, the affinity of the unoccupied receptors for LH was similar within stage of the cycle, i.e. pro-oestrus or dioestrus. However, as determined by analysis of variance, a genetic difference was found in the concentrations of available $\mathrm{LH}$ receptors during pro-oestrus: those measured in $\mathrm{Sl}$ tissues were greater $(P \leqslant 0.05)$ than those in $\mathrm{G}$ tissues (Fig. 3a). In contrast, LH receptor concentrations measured during dioestrus were higher in Line $\mathrm{G}$ than in Line $\mathrm{S} 1$ tissues (Fig. 3b).

\section{Discussion}

Selection for various traits in mice has produced substantial differences in ovulation rate (Falconer, 1960; Bradford, 1969; Bradford \& Nott, 1969; Land \& Falconer, 1969), oestrous cyclicity (Nobunaga, 1973; Barkley \& Bradford, 1981), reproductive hormone concentrations (Murr et al., 1973; Barkley et al., 1979; Stalvey \& Payne, 1983) and ovarian sensitivity to gonadotrophins (Spearow \& Bradford, 1983; Spearow, 1984). The present study extends these observations by demonstrating the nature of modified endocrine regulation of oestrous cyclicity following genetic selection. 


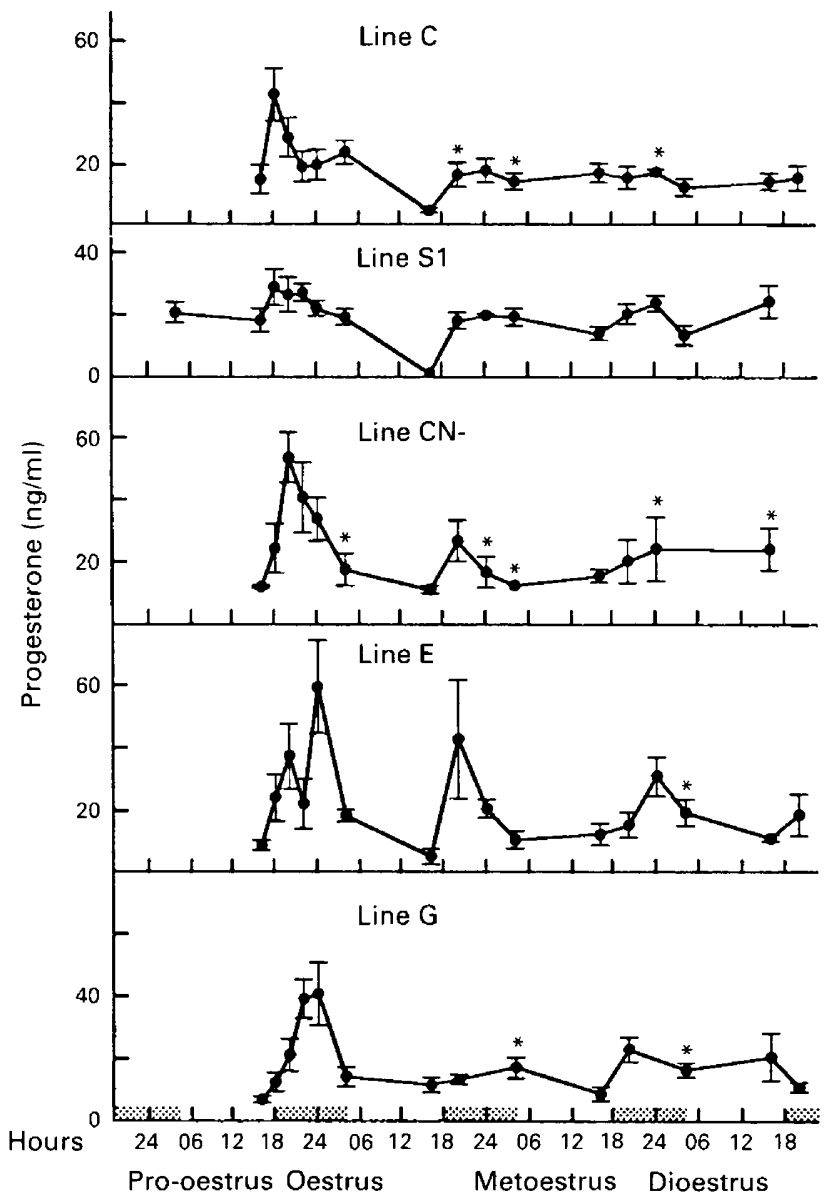

Fig. 2. Progesterone concentrations in plasma during the oestrous cycle in mice of Lines $\mathrm{C}, \mathrm{S} 1$, $\mathrm{CN}-, \mathrm{E}$ and $\mathrm{G}$. Each point on the graph represents the mean \pm s.e.m. for 5-13 animals, with the exception of 3-4 mice/group where indicated $\left({ }^{*}\right)$.

The general patterns of hormone secretion we report resemble those previously found during the oestrous cycle of the mouse (Murr et al., 1973; Michael, 1976) and the rat (Butcher et al., 1974; Smith et al., 1975). In our study increased secretion of prolactin and progesterone occurred during late pro-oestrus-early oestrus. Subsequently, the plasma concentrations of these hormones were reduced, usually by late oestrus. Within each strain, the secretory patterns of prolactin and progesterone were remarkably similar. This observation is notable in view of the ability of prolactin to stimulate progesterone production by rat granulosa cells (Fortune \& Vincent, 1986) and to increase ovarian LH receptor number during pro-oestrus (Muller et al., 1980; Richards, 1980). Prolactin is also required for progesterone synthesis by mouse luteal cells (Mednick et al., 1980).

Between-strain differences were evident in the timing of peak prolactin and progesterone secretion and the magnitude of prolactin release. Mice characterized by irregular oestrous cycles and poor reproductive performance (Lines $\mathrm{CN}$ - and $\mathrm{G}$ ) secreted higher prolactin concentrations than did randomly bred females (Line $\mathrm{C}$ ) or females with regular cycles and improved fertility (Lines E and S1). Prolactin can inhibit ovarian aromatase (Tsai-Morris et al., 1983) which could result in lower oestradiol production in mice of Lines $\mathrm{CN}$ - and G. Reduced oestrogen secretion could explain, at least in part, the irregular oestrous cycles and reduced fertility that typify these strains. 


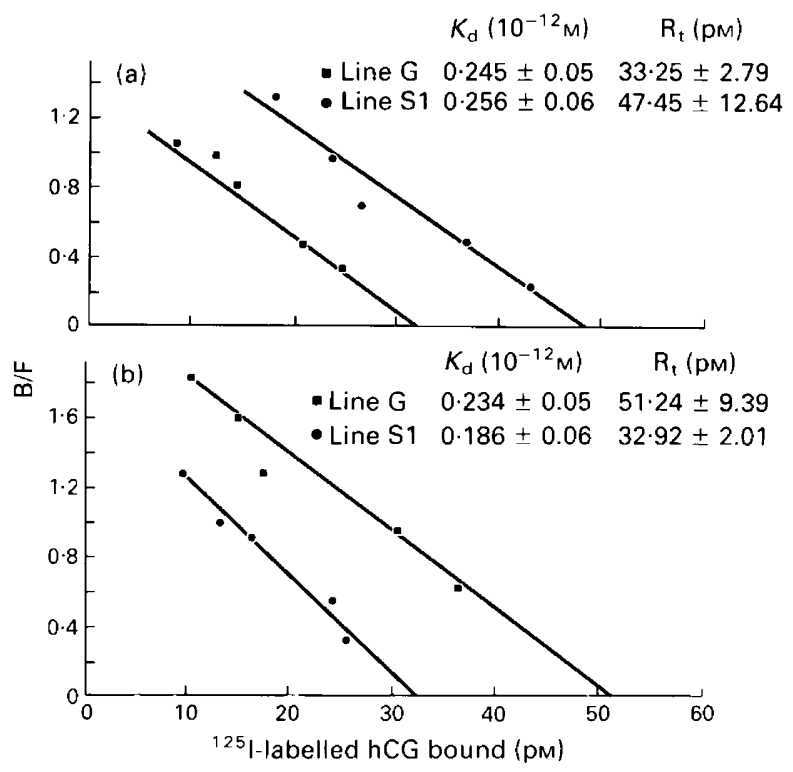

Fig. 3. Scatchard analyses of the specific binding of ${ }^{125} \mathrm{I}$-labelled hCG to ovarian homogenates obtained from mice during (a) pro-oestrus and (b) dioestrus. B/F represents specifically bound ${ }^{125}$ I-labelled hCG divided by unbound ${ }^{125}$ I-labelled hCG. Each point represents the mean of results obtained from saturation analyses of 3 pools of ovaries collected from 6 mice/pool.

The presence of an LH surge during mouse pro-oestrus (Bradford et al., 1980) and the dependency of this hormonal event on a preovulatory, incremental increase in oestradiol production in rodents provides indirect evidence that oestrogen secretion is not severely compromised in mice of Lines CN- and G. Since the dynamics of LH secretion are similar in the mouse (Bradford et al., 1980) and rat (Butcher et al., 1974; Smith et al., 1975), it is not surprising that the pattern of ovarian LH receptor content is essentially the same in both species. In the present study, which to our knowledge is the first to examine ovarian LH receptor concentration throughout the mouse oestrous cycle, an increased number of $\mathrm{LH}$ receptors was found during dioestrus and pro-oestrus as previously reported for the rat (Lee et al., 1975; Hacik \& Kolena, 1975; Bortolussi et al., 1979; Solano et al., 1980). In our study, LH receptor concentration could not be accurately quantified during oestrus and metoestrus due to non-specific binding indicative of a minimal number of available receptors during these stages of the cycle.

Consistent with other studies of $\mathrm{LH}$ receptor characteristics in the control and selected strains (Spearow, 1980, 1984), we found that the affinity of LH receptors did not vary with strain. Also, a lack of genetic influence on ovarian $\mathrm{LH}$ receptor number during dioestrus, seen previously in mice of Lines C, S1 and G (Spearow, 1980), was found using subsequent generations of Line S1 and G mice (Fig. 3b). In contrast, during pro-oestrus, Line $S 1$ mice had an elevated LH receptor concentration relative to that in Line $G$ animals. This could be accounted for by strain differences in the induction of LH receptors by FSH which can be potentiated by oestrogen (Richards, 1978). In support of this contention, major (6-9-fold) differences in LH receptor induction by diethylstilboestrol and FSH were found between immature females of Lines S1 and G (Spearow \& Bradford, 1983). A low rate of induction of LH receptors in immature FSH and diethylstilboestrol-treated females selected for large litters provides a fascinating contrast with the high LH receptor concentration found during pro-oestrus in the S1 mice in this study. An elevated FSH concentration (Spearow, 1980) and substantially increased oestradiol production during pregnancy in Line S1 (Barkley et al., 1979) are characteristics compatible with the potential for altered ovarian L $_{2} H_{3}$ 
receptor concentration as a function of reproductive status. Thus, in immature animals the rate of induction of $\mathbf{L H}$ receptors in Line $\mathrm{Sl}$ mice is low relative to that in Line G mice (Spearow \& Bradford, 1983), but in the untreated, pro-oestrous animal, ovarian LH receptor content increases to a greater extent than in Line $\mathrm{G}$.

Ovarian responsiveness to FSH and oestrogen alone cannot account for the regulation of $\mathrm{LH}$ receptor dynamics in the untreated female mouse. Another primary candidate for this action is prolactin which, in the rat, increases ovarian LH receptor number during pro-oestrus (Muller $e t$ al., 1980; Richards, 1980). If prolactin has a similar action in the mouse, it seems to be mediated by ovarian responsiveness to this hormone because $\mathrm{LH}$ receptor induction can be uncoupled from the circulating concentration of prolactin. For example, mice in line S1 have low prolactin concentrations and a higher number of ovarian $\mathrm{LH}$ receptors during pro-oestrus than do Line $\mathrm{G}$ mice, which are characterized by high prolactin values at this time. Ovarian LH receptor number in the mouse may also include regulation by autocrine or paracrine agents such as growth factors. For example, epidermal growth factor inhibits FSH-dependent induction of LH receptors in the rat (Mondschien \& Schomberg, 1981). Whether this level of regulation can explain genetic variation in $\mathrm{LH}$ receptor number is as yet unknown.

The temporal relationship between induction and occupancy of LH receptors and ovarian steroidogenesis is not well defined in the mouse. The amount of available tissue limited the present measurements to unoccupied receptors. Under these conditions, an inverse relationship between LH receptor concentration and progesterone production during pro-oestrus was suggested in Line S1 mice. In this line and another derived from it (Line S15), an increased number of unoccupied LH receptors is associated with lower steroid production (Spearow, 1985). This is not surprising in that gonadotrophin receptor concentration per se does not predict ovarian responsiveness to gonadotrophic stimulation. The essential role of cAMP in the regulation of de-novo P-450 ${ }_{17 \alpha}$ synthesis (Anakwe \& Payne, 1987) may contribute to strain differences in ovarian steroidogenesis, an hypothesis made attractive by the already demonstrated genetic variation in hCG-stimulated ovarian cAMP production in the mouse (Spearow, 1985). Altered sensitivity to LH and decreased steroidogenesis in male mice of different strains is greatly affected by the availability of enzymes involved in the critical steps of steroid synthesis (Bartke \& Shire, 1972; Stalvey \& Payne, 1984), a phenomenon that may also account for some of the variation we observed during the oestrous cycle.

Genetic variation of the nature we report can result from selection itself, as a correlated response to selection or as a result of random genetic drift. The three types of change cannot be distinguished in the model we studied because there are no replicative lines. However, the substantial effort made in the production of the control and selected lines, with a large number of mating pairs to reduce inbreeding, and the stable performance of these lines allow for the assumption that genetic drift is small. It should also be recognized that changes in hormone secretion and receptor concentration can arise in a number of different ways. Hormone release can be affected by hormone biosynthesis, altered sensitivity to positive and/or negative regulators, coupling to release mechanisms, metabolism and various other factors. As a direct or correlated response to selection for reproductive traits, variation in hormone binding could result from changes in such factors as induction and/or degradation of receptor, occupancy by endogenous hormone, and more ovarian receptor per follicle or more follicles per ovary, possibilities which the present study does not rule out and that require investigation. Indeed, genetic differences in hormone secretion (Murr et al., 1973; Barkley et al., 1979; Stalvey \& Payne, 1983), LH receptor induction (Spearow \& Bradford, 1983; Pomp et al., 1988), and ovarian and testicular LH receptor concentration in untreated mice (Purvis et al., 1978; Amador \& Bartke, 1981, 1982; Stalvey \& Payne, 1983) reflect contrasting physiological bases for response to selection.

We thank Dr J. L. Spearow for review of the manuscript. This work was supported by HD-00394 to M.S.B. and PHS GM08666 to D.D.Dloaded from Bioscientifica.com at 04/26/2023 07:32:34AM 


\section{References}

Amador, A. \& Bartke, A. (1981) Endocrinological Research. Mouse Newsletter 65, 46.

Amador, A. \& Bartke, A. (1982) Endocrinological Research. Mouse Newsletter 66, 77.

Anakwe, O.O. \& Payne, A.H. (1987) Noncoordinate regulation of de novo synthesis of cytochrome P-450 cholesterol side-chain cleavage and cytochrome P$45017 \alpha$-hydroxylase/ $\mathrm{C}_{17-20}$ lyase in mouse Leydig cell cultures: relation to steroid production. Molec. Endocr. 1, 595-603.

Aron, C. (1979) Mechanisms of control of the reproductive function by olfactory stimuli in female mammals. Physiol. Rev. 59, 229-284.

Barkley, M.S. \& Bradford, G.E. (1981) Estrous cycle dynamics in different strains of mice. Proc. Soc. exp. Biol. Med. 167, 70-77.

Barkley, M.S., Bradford, G.E. \& Geschwind, I.I. (1978) The pattern of plasma prolactin concentration during the first half of mouse gestation. Biol. Reprod. 19, 291-296.

Barkley, M.S., Geschwind, I.I. \& Bradford, G.E. (1979) The gestational pattern of estradiol, testosterone and progesterone secretion in selected strains of mice. Biol. Reprod. 20, 733-738.

Barkley, M.S., Bartke, A., Gross, D.S. \& Sinha, Y.N. (1982) Prolactin status of hereditary dwarf mice. Endocrinology 110, 2088-2096.

Barkley, M.S., Lasley, B.L., Thompson, M.A. \& Shackleton, C.H.L. (1985) Equol: a contributor to enigmatic measurements of estrogen. Steroids 46, 587-608.

Bartke, A. \& Shire, J.G.M. (1972) Differences between mouse strains in testicular cholesterol levels and androgen target organs. J. Endocr. 55, 173-184.

Bortolussi, M., Marini, G. \& Reolon, M.L. (1979) A histochemical study of the binding of ${ }^{125} \mathrm{I}-\mathrm{hCG}$ to the rat ovary throughout the estrous cycle. Cell Tiss. Res. 197, 213-226.

Bradford, G.E. (1968) Selection for litter size in mice in the presence and absence of gonadotropin treatment. Genetics, Princeton 58, 283-295.

Bradford, G.E. (1969) Genetic control of ovulation rate and embryo survival in mice. I. Response to selection. Genetics, Princeton 61, 905-921.

Bradford, G.E. (1971) Growth and reproduction in mice selected for body weight gain. Genetics, Princeton 69, 499-512.

Bradford, G.E. \& Nott, F.G. (1969) Genetic control of ovulation rate and embryo survival in mice. II. Effects of crossing select lines. Genetics, Princeton 63, 907-918.

Bradford, G.E., Barkley, M.S. \& Spearow, J.L. (1980) Physiological effects of selection for aspects of efficiency of reproduction. In Selection, pp. 161-174. Commonwealth Agricultural Bureaux.

Bradford, M.M. (1976) A rapid and sensitive method for the quantitation of microgram quantities of protein utilizing the principle of protein-dye binding. Analyt. Biochem. 72, 248-254.

Bramley, T.A. \& Ryan, R.J. (1978) Interactions of gonadotropins with corpus luteum membranes. I. Properties and distributions of some marker enzyme activities after subcellular fractionation of the superovulated rat ovary. Endocrinology 103, 778-795.

Butcher, R.L., Collins, W.E. \& Fugo, N.W. (1974) Plasma concentration of LH, FSH, prolactin, progesterone and estradiol-17 $\beta$ throughout the 4-day estrous cycle of the rat. Endocrinology 94, 1704-1708.

Catt, K.J., Dufau, M.L. \& Tsuruhara, T. (1972) Radioligand-receptor assay of luteinizing hormone and human chorionic gonadotropin. J. clin. Endocr. Metab. 34, 123-132.

DeLeon, D.D. \& Barkley, M.S. (1987) Male and female genotype mediate pheromonal regulation of the mouse estrous cycle. Biol. Reprod. 37, $1066-1074$.

Drickamer, L.C. (1975) Female maturation: relative importance of social factors and day length. $J$. Reprod. Fert. 44, 147-150.

Falconer, D.S. (1960) The genetics of litter size in mice. $J$. cell. comp. Physiol. 56, 153-167.

Fortune, J.E. \& Vincent, S.E. (1986) Prolactin modulates steroidogenesis by rat granulosa cells: I. Effects on progesterone. Biol. Reprod. 35, 8491.

Gibori, G., Antczak, E. \& Rothchild, I. (1977) The role of estrogen in the regulation of luteal progesterone secretion in the rat after Day 12 of pregnancy. Endocrinology 100, 1483-1495.

Hacik, T. \& Kolena, J. (1975) Binding of human chorionic gonadotropin by rat ovarian tissues. Endokrinologie 66, 15-23.

Ketelslegers, J.M., Knott, G.D. \& Catt, K.J. (1975) Kinetics of gonadotropin binding by receptors of the rat testis. Analyses by a non-linear curve-fitting method. Biochemistry, NY 14, 3075-3082.

Land, R.B. \& Falconer, D.S. (1969) Genetic studies of ovulation rate in the mouse. Genet. Res. 13, 25-46.

Lee, C.Y., Kayoko, T., Ryan, R.J. \& Jiang, N.S. (1975) Binding of human chorionic gonadotropin by rat ovarian slices: Dependence on the functional state of the ovary. Proc. Soc. exp. Biol. Med. 148, 505-507.

Mednick, D.L., Barkley, M.S. \& Geschwind, I.I. (1980) Regulation of progesterone secretion by $\mathrm{LH}$ and prolactin during the first half of pregnancy in the mouse. J. Reprod. Fert. 60, 201-207.

Michael, S.D. (1976) Plasma prolactin and progesterone during the estrous cycie in the mouse. Proc. Soc. exp. Biol. Med. 153, $254-257$.

Mondschein, J.S. \& Schomberg, D.W. (1981) Growth factors modulate gonadotropin receptor induction in granulosa cell cultures. Science, $N Y$ 211, 1179-1180.

Morrison, M. \& Bayse, G.D. (1970) Catalysis of iodination by lactoperoxidase. Biochemistry, $N Y \mathbf{9}$, 2995-3000.

Muller, U., Bauknecht, T.H. \& Siebers, J.W. (1980) Regulation of $\mathrm{LH} / \mathrm{HCG}$ receptors during the ovarian cycle in rats. Arch. Gynecol. 230, 137-142.

Murr, S.M., Geschwind, I.I. \& Bradford, G.E. (1973) Plasma LH and FSH during different oestrous cycle conditions in mice. J. Reprod. Fert. 32, 221-230.

Nelson, J.F., Felicio, L.S., Randall, P.K., Sims, C. \& Finch, C.E. (1982) A longitudinal study of estrous cyclicity in aging C57BL/6J mice. I. Cycle frequency, length and vaginal cytology. Biol. Reprod. 27, 327-339.toaded from Bioscientifica.com at 04/26/2023 07:32:34AM 
Nobunaga, T. (1973) Establishment by selective inbreeding of the IVCS strain and related sister strains of the mouse, demonstrating regularly repeated 4-day estrous cycles. Lab. Anim. Sci. 23, 803-811.

Pomp, D., Eisen, E.J. \& Ziecik, A.J. (1988) LH receptor induction and ovulation rate in mice selected for litter size and body weight. J. Reprod. Fert. 84, 601-610.

Purvis, K., Clausen, O.P.F. \& Hansson, V. (1978) Decreased Leydig cell responsiveness in the testicular feminized rat. Endocrinology 102, 1053-1060.

Richards, J.S. (1978) Hormonal control of follicular growth and maturation in mammals. In The Vertebrate Ovary, pp. 331-360. Ed. R. E. Jones. Plenum Press, New York.

Richards, J.S. (1980) Hormone regulation of ovarian hormone receptors. Receptors and Hormone Action, VIII, 479-491.

Scatchard, G. (1949) The attractions of proteins for small molecules and ions. Ann. N.Y. Acad. Sci. 51, 660-672.

Smith, M.S., Freeman, M.E. \& Neill, J.D. (1975) The control of progesterone secretion during the estrous cycle and early pseudopregnancy in the rat: Prolactin, gonadotropin and steroid levels associated with rescue of the corpus luteum of pseudopregnancy. Endocrinology 96, 219-226.

Solano, A.R., Garcia-Vela, A., Catt, K.J. \& Dufau, M.L. (1980) Regulation of ovarian gonadotropin receptors and $\mathrm{LH}$ bioactivity during the estrous cycle. FEBS Letters 122, 184-188.

Spearow, J.L. (1980) The physiological basis of genetic differences in the ovulation rate of mice. $\mathrm{Ph} . \mathrm{D}$. disser- tation, University of California, Davis. [Diss. Abstr. No. 8027089.]

Spearow, J.L. (1984) The mechanism of action of genes controlling gonadal function. Proc. 10th Int. Congr. Anim. Reprod. \& A.I., Urbana-Champaign, 6, 9-16.

Spearow, J.L. (1985) The mechanism of action of genes controlling reproduction. In Genetics of Reproduction in Sheep, pp. 203-215. Eds R. B. Land \& D. W. Robinson. Butterworth, London.

Spearow, J.L. \& Bradford, G.E. (1983) Genetic variation in spontaneous ovulation rate and $\mathrm{LH}$ receptor induction in mice. J. Reprod. Fert. 69, 529-537.

Stalvey, J.R.D. \& Payne, A.H. (1983) Luteinizing hormone receptors and testosterone production in whole testes and purified Leydig cells from the mouse: Differences among inbred strains. Endocrinology 112, $1696-1701$

Stalvey, J.R.D. \& Payne, A. (1984) Maximal testosterone production in Leydig cells from inbred mice relates to the activity of $3 \beta$-hydroxysteroid dehydrogenaseisomerase: Endocrinology 225, 1500-1505.

Tsai-Morris, C.H., Ghosh, M., Hirshfield, A.N., Wise, P.M. \& Brodie, A.M.H. (1983) Inhibition of ovarian aromatase by prolactin in vivo. Biol. Reprod. 29, 342-346.

Vom Saal, F.S., Pryor, S. \& Bronson, F.H. (1981) Effects of prior intrauterine position and housing on oestrous cycle length in adolescent mice. J. Reprod. Fert. 62, 33-37.

Received 4 August 1989 